\title{
Maximal cutaneous blood flow in vibration white fingers
}

\author{
F BOUVIER, C-J GÖTHE, L-E LINDBLAD
}

From the Departments of Clinical Physiology and Occupational Medicine, Södersjukhuset, S-100 64 Stockholm, Sweden

Long term work with vibrating tools often results in attacks of cold induced reduction of the blood flow in finger arteries ("vibration white finger"-VWF). Organic obstruction of the digital arteries due to hypertrophy of the vessel walls ${ }^{23}$ and subintimal fibrosis ${ }^{4}$ have been proposed as a possible pathophysiological mechanism. With plethysmographic methods, however, similar maximal blood flows are observed in VWF fingers as in normal fingers of workers not exposed to vibration. ' Plethysmography measures the total rather than the cutaneous blood flow and the aim of the present study was to examine the maximal superficial cutaneous blood flow in VWF and normal fingers.

\section{Material and methods}

Eleven otherwise healthy patients with VWF corresponding to grades 3 and 4 according to the Taylor and Pelmear symptom scale ${ }^{5}$ were studied. The mean age of the patient group was $44 \cdot 5$ years (range 25-61). The controls were 11 male white collar workers without vascular disease individually matched to the patients with regard to age ( \pm 5 years) and nicotine habits (users, non-users).

In every patient the most and least affected fingers, and in the controls one of the three medial fingers, were examined. The blood flow in the fingers exposed in $\mathrm{ml} /$ minute and $100 \mathrm{~g}$ tissue was measured according to Sejrsen. ${ }^{6}$ On the dorsum of the middle phalanx, $0.2 \mathrm{ml}$ of ${ }^{133} \mathrm{Xe}$ dissolved in physiological saline $(1388 \mathrm{MBq} / \mathrm{ml})$ was applied in a water and gas proof chamber attached to the finger with plaster. The skin was exposed to the ${ }^{133} \mathrm{Xe}$-solution for three minutes to allow a small Xe-fraction to penetrate into the cutis. The chamber was then removed and the skin cleaned by gentle wiping. The elimination of ${ }^{133} \mathrm{Xe}$ was measured with a gamma detector (Mini Scaler MS-2, Eberline Instrument Corp). The wash out rate of ${ }^{133} \mathrm{Xe}$ gives a measure of the cutaneous blood flow.

The measurements were performed with the subjects in supine position and their hands located at heart

Accepted 30 January 1989 level. The room temperature was $27^{\circ} \pm 1^{\circ} \mathrm{C}$ and the $\vec{\omega}$ finger temperatures ranged between $33^{\circ}$ and $36.5^{\circ} \mathrm{C}$. $\mathrm{S}$ Before the first blood flow measurement, vasodilation was induced with oral intake of $5 \mathrm{cl}$ of $50 \%$ ethanol combined with indirect heating of the abdomen for $20 \stackrel{\mathrm{\sigma}}{\mathrm{s}}$ minutes. After this, arterial occlusion was applied on $\vec{N}$ the examined finger for three minutes, and during the phase of postocclusive vasodilation another estima- $\mathrm{N}$ tion of blood flow ("maximal cutaneous blood flow")을 was done.

\section{Results}

Before arterial occlusion there is a numerical but statistically non-significant $(p>0.05)$ tendency to lower blood flow in the most affected VWF fingers $a s \overline{0}$ compared with the least affected VWF fingers amd control fingers (table). During the postocclusiye vasodilation, the mean flows are about the same both VWF and control fingers.

\section{Discussion}

After vasodilation the cutaneous blood flow of theo fingers is the same in patients with VWF as in healthy subjects which corresponds to earlier findings using plethysmographic methods. ${ }^{1}$ The means are similar in all groups. Consequently, it is unlikely that a real ${ }_{\mathbb{\Phi}}$ difference is masked by the variation.

The observation that the cutaneous blood flow: during intense vasodilation is about the same in VWF

Cutaneous blood flow (ml/minute and $100 \mathrm{~g}$ tissue) in fingers of patients with $V W F$ and in fingers of white collar workers without vascular disease (mean $\pm S D$ )

\begin{tabular}{llll}
\hline & \begin{tabular}{l} 
VWF fingers \\
\cline { 2 - 4 } \\
$(n=I 1)$
\end{tabular} & $\begin{array}{l}\text { Least affected affected } \\
(n=I I)\end{array}$ & $\begin{array}{l}\text { Control fingers } \\
(n=11)\end{array}$ \\
\hline $\begin{array}{c}\text { Before postocclusive } \\
\text { vasodilation }\end{array}$ & $20.4 \pm 8.56$ & $28.1 \pm 12.8$ & $27.7 \pm 13.03$ \\
$\begin{array}{c}\text { After postocclusive } \\
\text { vasodilation }\end{array}$ & $75.5 \pm 34.90$ & $82.5 \pm 40.49$ & $75.6 \pm 16.04$ \\
\hline
\end{tabular}


fingers as in non-affected fingers of subjects not exposed to vibrations further confirms that the attacks of reduced blood flow in VWF are mainly due to reversible vasospasm.

\section{References}

1 Ekenvall L, Lindblad LE, Bevegård S, Etzell BM. High vascular tone but no obliterative lesions in vibration white fingers. $\mathrm{Am} \mathrm{J}$ Ind Med 1986;12:47-54.
2 Pyykkö I, Hyvärinen J. Vibration induced changes of sympathetic vasomotor tone. Acta Chir Scand 1976;suppl 465:23-6.

3 Takeuchi T, Futatsuka M, Imanishi H, Yamada S. Pathological changes observed in the finger biopsy of patients with vibration induced white finger. Scand J Work Environ Health 1986;12: 280-3.

4 Hashimoto K, Craig RS. Acrosclerosis associated with vibration: an electron microscopic study. J Cutan Pathol 1980;7:373-86.

5 Taylor W, Palmear PL. Raynaud's phenomenon of occupational origin. An epidemiological survey. Acta Chir Scand 1976;20: 27-32.

6 Sejrsen P. Blood flow in cutaneous tissue in man. Studied by washout of radioactive xenon. Circ Res 1969;25:215-29. 